\title{
Loss of the $\mathrm{Na}^{+} / \mathrm{H}^{+}$Exchange Regulatory Factor 1 Increases Susceptibility to Cisplatin- Induced Acute Kidney Injury
}

Adrienne Bushau-Sprinkle, ${ }^{*}$ Michelle Barati, ${ }^{\dagger}$ Caryl Conklin, ${ }^{\dagger}$ Tess Dupre, ${ }^{*}$ Kenneth B. Gagnon, ${ }^{\dagger}$ Syed J. Khundmiri, Barbara Clark, ${ }^{\S}$ Leah Siskind, ${ }^{*}$ Mark A. Doll, ${ }^{*}$ Madhavi Rane, ${ }^{\dagger}$ Michael Brier, ${ }^{* \dagger}$ Susan Coventry, ${ }^{\mathbb{}\|\|}$ and Eleanor D. Lederer ${ }^{\dagger * *}$

From the Department of Pharmacology and Toxicology, ${ }^{*}$ the Department of Medicine, ${ }^{\dagger}$ Division of Nephrology, and the Departments of Biochemistry and

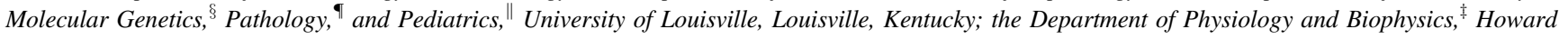
University, Washington, DC; and the Robley Rex VA Medical Center, ** Louisville, Kentucky

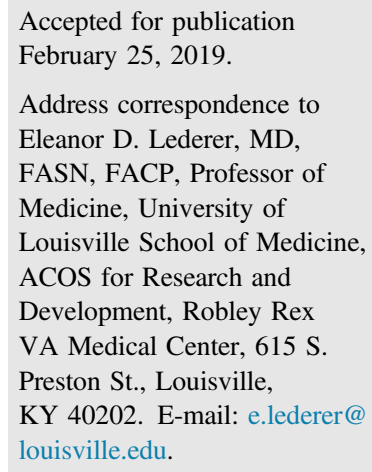

\begin{abstract}
$\mathrm{Na}^{+} / \mathrm{H}^{+}$exchange regulatory cofactor (NHERF)-1, a scaffolding protein, anchors multiple membrane proteins in renal proximal tubules. Cultured proximal tubule cells deficient in Nherf1 and proximal tubules from Nherf1-deficient mice exhibit aberrant trafficking. Nherf1-deficient cells also exhibit an altered transcription pattern and worse survival. These observations suggest that NHERF1 loss increases susceptibility to acute kidney injury (AKI). Male and female wild-type C57BL/6J and Nherf1 knockout mice were treated with saline or cisplatin $(20 \mathrm{mg} / \mathrm{kg}$ dose i.p.) to induce AKI and were euthanized after 72 hours. Blood and urine were collected for assessments of blood urea nitrogen and neutrophil gelatinase-associated lipocalin, respectively. Kidneys were harvested for histology (hematoxylin and eosin, periodic acid-Schiff) and terminal deoxynucleotidyl transferase dUTP nick end labeling assay, Kim1 mRNA assessment, and Western blot analysis for cleaved caspase 3. Cisplatin treatment was associated with significantly greater severity of AKI in knockout compared with wild-type mice, as demonstrated by semiquantitative injury score $(2.8$ versus $1.89, P<0.001)$, blood urea nitrogen $(151.8 \pm 17.2 \mathrm{mg} / \mathrm{dL}$ versus $97.8 \pm 10.1 \mathrm{mg} / \mathrm{dL}, P<0.05)$, and neutrophil gelatinase-associated lipocalin urine protein $(55.6 \pm 21.3 \mu \mathrm{g} / \mathrm{mL}$ versus $2.7 \pm 0.53 \mu \mathrm{g} / \mathrm{mL}, P<0.05)$. Apoptosis markers were significantly increased in cisplatin-treated Nherf1 knockout and wild-type mice compared to respective controls. These data suggest that NHERF1 loss increases susceptibility to AKI. (Am J Pathol 2019, 189: 1190-1200; https://doi.org/10.1016/j.ajpath.2019.02.010)
\end{abstract}

Cisplatin is a chemotherapeutic agent widely used in treating a variety of solid malignant tumors (eg, ovarian, testicular, head and neck, and lung cancers). ${ }^{1,2}$ Cisplatin was approved by the US Food and Drug Administration in 1978 for the treatment of advanced ovarian and bladder cancers and is one of the most widely used antitumor drugs in the world. Unfortunately, the major dose-limiting factor of cisplatin is its associated nephrotoxicity. Cisplatin-related nephrotoxicity can present in a variety of ways, but the most serious and common presentation is acute kidney injury (AKI). AKI complicates $1 \%$ to $7 \%$ of all hospital admissions and $1 \%$ to $25 \%$ of intensive care unit admissions, ${ }^{1,3,4}$ increases the risk for death by 10 - to 15 -fold, and is associated with a $50 \%$ mortality rate. ${ }^{1,5,6}$ Currently, 20\% to $30 \%$ of patients receiving a single dose of cisplatin will develop
AKI. ${ }^{7}$ Clinically, cisplatin-related nephrotoxicity typically develops after 10 days of administration, and the prevalence of nephrotoxicity increases with repeated doses. ${ }^{8}$ Permanent nephrotoxicity can occur if successive treatment courses are

Supported in part by US Department of Veterans Affairs Biomedical Laboratory Research and Development Service Merit Review Award R01DK083361 (E.D.L.).

Disclosures: E.D.L. is a consultant for WebMD and Healthcare Quality Strategies, Inc. (HQSI).

The views in the manuscript are those of the author and do not reflect the views of the US Department of Veterans Affairs.

Current address of C.C., Institute of Cellular Therapeutics, University of Louisville, Louisville, KY; of T.D., Department of Pharmacology and Toxicology, University of Arizona, Phoenix, AZ. 
continued. ${ }^{2}$ In addition, cisplatin-induced AKI frequently progresses to chronic kidney disease, a risk factor for early death. Despite extensive research, the mechanism of cisplatininduced AKI is not completely understood, and there are currently no US Food and Drug Administration-approved therapies to halt or reverse AKI progression. Furthermore, clinicians have no good tools for predicting the likelihood of cisplatin-related nephrotoxicity in the individual patient. If a renoprotective therapy is to be developed, the mechanisms behind susceptibility to cisplatin-induced AKI and at-risk populations must be better understood and novel targets identified.

The goal of this study was to determine whether the expression of the scaffolding protein $\mathrm{Na}^{+} / \mathrm{H}^{+}$exchange regulatory cofactor (NHERF)-1 influences the development of cisplatin-induced AKI. NHERF1 is a membrane-associated protein of the NHERF family of PDZ-scaffold proteins that contain two postsynaptic density protein-95/Drosophila discs large/zonula occludens 1 homology domains in the $\mathrm{N}$-terminal half of the protein, and a C-terminal MERM (moesin, ezrin, radixin, merlin) domain (residues 242 to 358 ), ${ }^{9,10}$ which anchors it to the cytoskeleton in the subapical plasma membrane region. ${ }^{11}$ NHERF1 is expressed in all types of epithelial cells and provides a scaffold for multiprotein signaling complexes. In proximal tubule cells, NHERF1 is a key scaffolding protein for transport proteins and has a crucial role in defining the renal proximal tubule brush border membrane composition and in regulating ion transport. ${ }^{9,11,12}$ Recent studies, however, suggest a much broader role for NHERF1 in human biology, including tumorigenesis, ${ }^{13,14}$ generation of cellular reactive oxygen species, ${ }^{15}$ and response to injury. ${ }^{16}$ Studies have demonstrated that cholestatic liver injury induced by bile duct ligation is attenuated in Nherf1 knockout (KO) mice, suggesting a role for NHERF1 in response to injury. ${ }^{16}$ NHERF1 has also been implicated in renal injury. Spontaneously hypertensive rats and aging rats (22 months) show a marked decrease in renal Nherf1 expression. ${ }^{17}$

Previous unpublished observations from our laboratory comparing wild-type (WT) and Nherf1-deficient opossum kidney cells, a model of mammalian renal proximal tubule, demonstrated that although there were no apparent morphologic differences between the cell lines, the Nherf1-deficient cells grew more slowly and were more likely to die in culture. The Nherf1-deficient cells exhibited markedly diminished expression of multiple brush border membrane proteins, including the sodium phosphate cotransporter Npt2a. ${ }^{18}$ Additionally, Nherf1-deficient cells in culture showed a decrease in the expression of Npt2a mRNA, which was rescued by transfection of Nherf1. ${ }^{18}$ When transfected with Npt2a constructs, Nherf1-deficient cells showed faulty membrane protein trafficking. ${ }^{18}$ These properties of the Nherf1-deficient cells (the poor survival, alterations in transcription pattern, and aberrant trafficking) suggest that NHERF1 deficiency may be associated with kidney injury. Based on these observations, we proposed the hypothesis that a loss of NHERF1 results in increased susceptibility to cisplatin-induced AKI.

\section{Materials and Methods}

\section{Reagents and Antibodies}

The following antibodies were purchased from Cell Signaling Technology (Beverly, MA): cleaved caspase 3 and glyceraldehyde-3-phosphate dehydrogenase. Horseradish peroxidase-conjugated secondary antibodies were purchased from Cell Signaling Technology. Pharmaceuticalgrade cisplatin was purchased from the University of Louisville hospital pharmacy (Louisville, KY), and was used for animal experiments. All other chemicals were purchased from Sigma-Aldrich (St. Louis, MO) unless otherwise specified.

\section{Animals and Treatments}

Two-month-old male and female C57BL/6J WT and Nherfl ${ }^{-1-}$ KO mice ${ }^{19}$ were maintained on a 12-hour light-dark cycle and were provided water and food ad libitum. Mice received a single i.p. injection of $20 \mathrm{mg} / \mathrm{kg}$ cisplatin or vehicle (saline). Vehicle- and cisplatin-treated mice were euthanized after 72 hours. All studies were performed at the same time each day. Blood samples were collected from these mice and plasma was extracted via centrifugation $(10,000 \times g$ for 10 minutes) to measure blood urea nitrogen (BUN) levels. Kidneys were removed and decapsulated; one kidney was immersed in $3.7 \%$ formaldehyde in phosphate-buffered saline for 24 hours and transferred to $70 \%$ ethanol before paraffin embedding for histology, while the other kidney was decapsulated and collected in ice-cold phosphate-buffered saline with $1 \%$ penicillin/streptomycin. The cortex was separated from the medulla for homogenization, and portions of the kidney tissue were snap-frozen in liquid nitrogen for RNA isolation. All animals in these studies were used in accordance with the guidelines established by the Institutional Animal Care and Use Committee at the University of Louisville, and the guidelines of the American Veterinary Medical Association.

\section{Histology and Semiquantitative Scoring}

Whole kidney sections were embedded in paraffin and cut 5 $\mu \mathrm{m}$ thick either transversely or longitudinally from cisplatinand vehicle-treated WT and Nherfl KO animals. These sections were stained with hematoxylin and eosin $(\mathrm{H} \& \mathrm{E})$ as well as periodic acid-Schiff (PAS). A renal pathologist (S.C.) determined the degree of morphologic changes and injury in a blinded fashion. The following measures were chosen as an indication of morphologic damage to the kidney after treatment with vehicle or cisplatin: acute proximal tubular cell necrosis, loss of the brush border, proximal tubule cell detachment, and tubular casts. These measures were evaluated on a 4-point scale: 0 (none) indicates normal kidney; $1+$ (mild) indicates primarily normal kidney with only occasional casts involving 
$<5 \%$ atrophy with spotty acute tubular necrosis; $2+$ (moderate) indicates patchy injury with casts and atrophy involving $25 \%$ to $50 \%$ and spotty acute tubular necrosis; and $3+$ (severe) indicates diffuse casts and atrophy $>50 \%$ area along with spotty acute tubular necrosis. The numbers of mice per group were as follows: WT female, $n=8$; Nherfl KO male, $n=9$; WT male, $n=11$; and Nherf 1 KO female $n=11$.

\section{Blood Urea Nitrogen and Neutrophil Gelatinase-Associated Lipocalin Measurements}

BUN was determined from blood plasma using the Catalyst Dx Chemistry Analyzer and BUN Urea Test Clips (Idexx Laboratories, Westbrook, ME) for quantitative measurement. The numbers of mice per group were as follows: Nherfl KO male vehicle, $n=5$; Nherfl $\mathrm{KO}$ female vehicle, $n=5$; WT male vehicle, $n=6$; WT male cisplatin, $n=6$; Nherfl KO male cisplatin, $n=6$; Nherf1 KO female cisplatin, $n=6$; WT female cisplatin, $n=7$; and WT female vehicle, $n=11$. Neutrophil gelatinase-associated lipocalin (NGAL) was determined using an enzyme-linked immunosorbent assay kit (catalog number DY1857; R\&D Systems; Minneapolis, MN) on mouse urine, as directed by the manufacturer. The numbers of mice per group were as follows: Nherfl KO female vehicle, $n=2$; Nherfl KO male vehicle, $n=3$; WT male vehicle, $n=3$; WT male cisplatin, $n=4$; Nherf1 KO male cisplatin, $n=4$; Nherf1 KO female cisplatin, $n=5$; WT female vehicle, $n=9$; and WT female cisplatin, $n=11$.

\section{RNA Isolation and Quantitative RT-PCR}

Total RNA was isolated from kidney cortex using the Ambion mirVana mRNA Isolation Kit (Thermo Fisher Scientific, Austin, TX) per the manufacturer's instructions. cDNA was synthesized from $1000 \mathrm{ng}$ of total RNA using SuperScript Vilo MasterMix (Thermo Fisher Scientific) following the manufacturer's instructions. Kidney injury molecule (Kim)-1 (catalog number Mm00506686; Thermo Fisher Scientific) and the housekeeping gene $\beta_{2}$ microglobulin $(B 2 \mathrm{~m}$; catalog number Mm00437762; Thermo Fisher Scientific) were used in combination with TaqMan Gene Expression Master Mix (Applied Biosystems, Foster City, CA). Amplification reactions were performed using the Applied Biosystems 7500 Real-Time PCR System and Sequence Detection software version 1.3.1 (Applied Biosystems), with stage $1\left(50^{\circ} \mathrm{C}\right.$ for 2 minutes), stage $2\left(95^{\circ} \mathrm{C}\right.$ for 10 minutes), and 40 cycles of a 2 -step PCR $\left(95^{\circ} \mathrm{C}\right.$ for 15 seconds, $60^{\circ} \mathrm{C}$ for 1 minute). Fluorescence intensity of each sample was measured at each cycle to monitor amplification of the target gene. The comparative cycle threshold method was used to determine fold-changes in mRNA expression compared to an endogenous reference gene $(B 2 \mathrm{~m})$. The numbers of mice per group were as follows: WT male vehicle, $n=5$; WT female vehicle, $n=5$; Nherf $1 \mathrm{KO}$ male vehicle, $n=5$; Nherf $1 \mathrm{KO}$ female vehicle, $n=5$; WT male
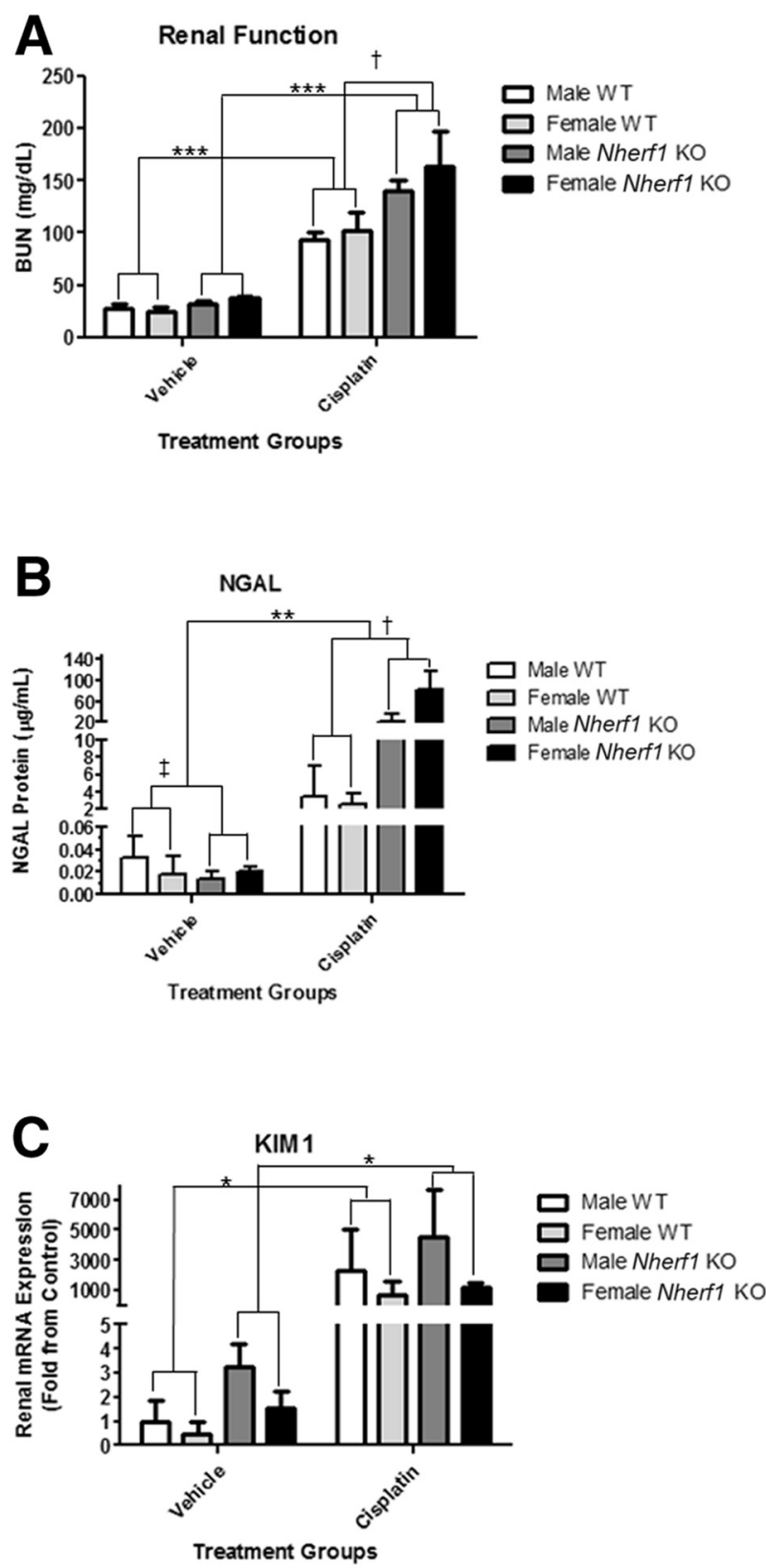

Figure 1 Effect of cisplatin on renal function in wild-type (WT) and Nherf1 knockout (K0) mice. Two-month-old male and female C57BL/6J WT and Nherf1 $\mathrm{KO}$ mice were given cisplatin (20 mg/kg dose i.p.) or vehicle (saline) and sacrificed after 72 hours as described in Materials and Methods. Renal function was determined. A: Blood urea nitrogen (BUN) measurement from mouse plasma. B: Neutrophil gelatinase-associated lipocalin (NGAL) protein measurement of mouse urine. C: Renal cortex mRNA expression of Kim1 by quantitative RT-PCR. Data are expressed as means \pm SEM. $n=2$ (Nherf1 K0 female vehicle, B); $n=3$ (WT male vehicle, Nherf1 K0 male vehicle, B); $n=4$ (WT male cisplatin and Nherf1 $\mathrm{KO}$ male cisplatin, B); $n=$ 5 (Nherf1 K0 male vehicle and Nherf1 K0 female vehicle, A; Nherf1 K0 female cisplatin, B; WT male vehicle, WT female vehicle, Nherf1 K0 male vehicle, Nherf1 K0 female vehicle, WT male cisplatin, WT female cisplatin, Nherf1 K0 male cisplatin, and Nherf1 K0 female cisplatin, C); $n=6$ (WT male vehicle, WT male cisplatin, Nherf1 K0 male cisplatin, and Nherf1 K0 female cisplatin, A); $n=7$ (WT female cisplatin, A); $n=9$ (WT female vehicle, B); $n=11$ (WT female vehicle, A; WT female cisplatin, B). ${ }^{*} P<0.05 ;{ }^{*} P<0.01 ;{ }^{* *} P<0.001 ;{ }^{\dagger} P<0.05 ;{ }^{\ddagger} P<0.05$ (three-way analysis of variance). 


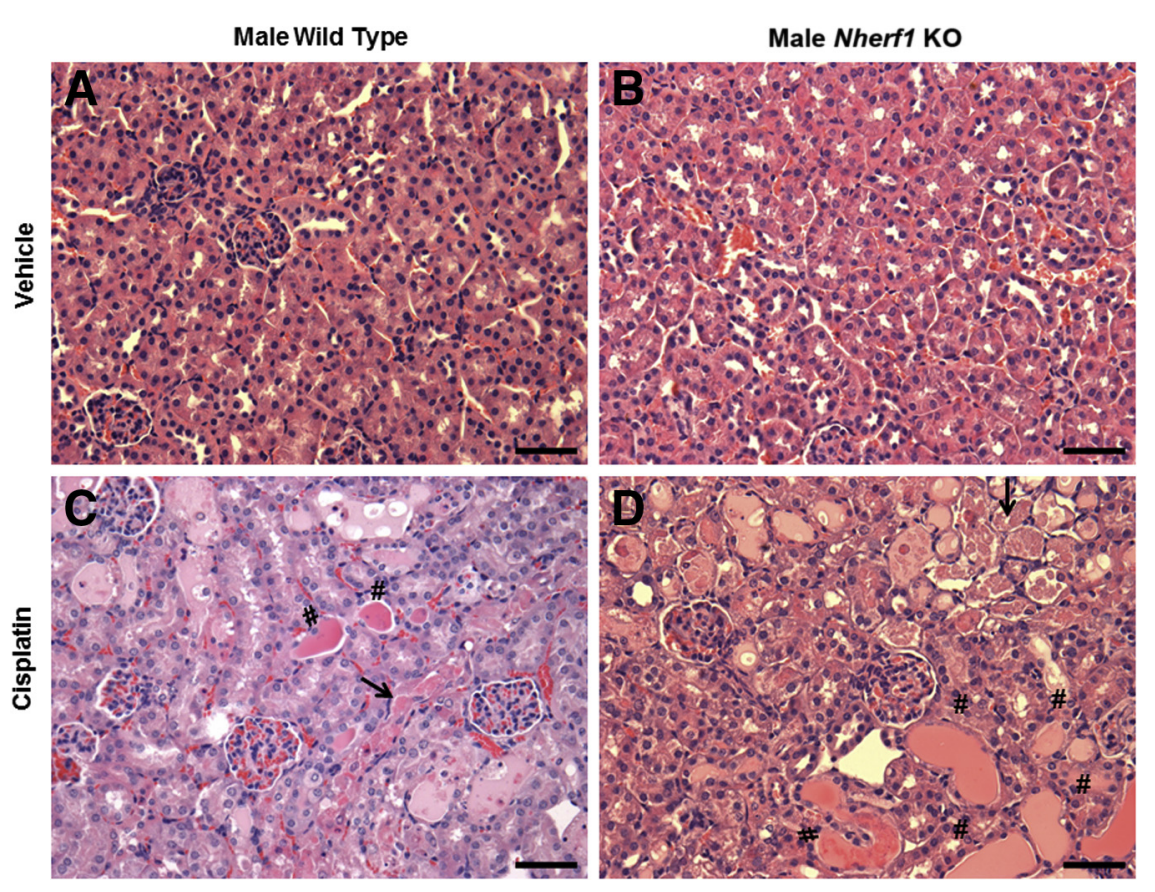

Figure 2 The histologic effect of cisplatin on hematoxylin and eosin (H\&E) in male wild-type (WT) and Nherf1 knockout (KO) mice. Representative photomicrographs of H\&E staining of whole kidney sections embedded in paraffin and cut at 5 $\mu \mathrm{m}$ thick either transversely or longitudinally from cisplatin- and vehicle-treated WT and Nherf1 KO male animals. A-D: A vehicle-treated male WT kidney (A), a vehicle-treated male Nherf1 KO kidney (B), a cisplatin-treated male WT kidney $(\mathbf{C})$, and a cisplatin-treated male Nherf1 K0 kidney (D). Arrows indicate acute tubular necrosis; pound signs indicate tubular casts. Scale bars: $50 \mu \mathrm{m}$. Original magnification, $\times 40$.

cisplatin, $n=5$; WT female cisplatin, $n=5$; Nherf1 KO male cisplatin, $n=5$; and Nherfl $\mathrm{KO}$ female cisplatin, $n=5$.

\section{TUNEL Assay}

Terminal deoxynucleotidyl transferase dUTP nick end labeling (TUNEL) assay was performed using the ApopTag Plus Peroxidase in situ apoptosis kit (EMD Millipore, Billerica, MA) per the manufacturer's instructions. Whole kidney sections were counterstained with hematoxylin for automation in conjunction with 3,3-diaminobenzidine substrate to visualize cell nuclei. Quantitation of TUNEL-positive nuclei was conducted in a blinded fashion (A.B.-S.), and only positively stained nuclei exhibiting characteristics of apoptotic nuclei, such as nuclear condensation and fragmentation, were included. Furthermore, positively stained nuclei on the outer edges of the sections were omitted during analysis. Randomly chosen visual fields (20 to 30) were observed under a $\times 40$ objective. Data are expressed as the ratio between the number of TUNEL-positive nuclei and the total number of visual fields. Kidney sections from 17 to 20 mice per group were used for this analysis. The numbers of mice per group were as follows: Nherf $1 \mathrm{KO}$ male vehicle, $n=7$; WT male vehicle, $n=10$; WT female vehicle, $n=10$; Nherfl KO female vehicle, $n=10$; WT male cisplatin, $n=$ 10 ; WT female cisplatin, $n=10$; Nherf 1 KO male cisplatin, $n=10$; and Nherfl KO female cisplatin, $n=10$.

\section{Protein Determination and Immunoblots}

Kidney cortex homogenates were made as previously described. ${ }^{17}$ Protein concentration was measured by the bicinchoninic acid method (Sigma-Aldrich) using bovine serum albumin as a standard. Kidney homogenates were separated by $10 \%$ SDS-PAGE and transferred to nitrocellulose membranes. The membranes were incubated with 5\% (w/v) dried milk in Tris-buffered saline with $0.5 \%$ Tween 20 (TTBS) for 30 minutes to decrease nonspecific antibody binding. Membranes were incubated overnight at $4{ }^{\circ} \mathrm{C}$ with primary antibodies diluted (1:1000) in 5\% milk. Membranes were washed with TTBS and incubated for 2 hours with horseradish peroxidase-conjugated secondary antibodies diluted in TTBS and 5\% milk. Chemiluminescence (Thermo Fisher Scientific) was utilized to detect bands and visualization via GeneSys software version 4.03(b) with a Pixi imaging system (Syngene, Bangalore, India). Densitometric analysis was performed via ImageJ software version $1.53 \mathrm{a}$ (NIH, Bethesda, MD; http://imagej.nih.gov.ij). For densitometric analysis, specific protein expression was normalized to densitometry values for glyceraldehyde-3phosphate dehydrogenase in each lane. The numbers of mice per group were as follows: WT male vehicle, $n=4$; WT female vehicle, $n=4$; Nherfl KO male vehicle, $n=4$; Nherf1 KO female vehicle, $n=4$; WT male cisplatin, $n=$ 4; WT female cisplatin, $n=4$; Nherf 1 KO male cisplatin, $n=4$; and Nherfl $\mathrm{KO}$ female cisplatin, $n=4$.

\section{Statistical Analysis}

Data are expressed as means \pm SEM. Three-way analysis of variance was used to compare the different treatment groups. Ordinal regression was performed for the semiquantitative scoring. All statistical analysis was conducted 

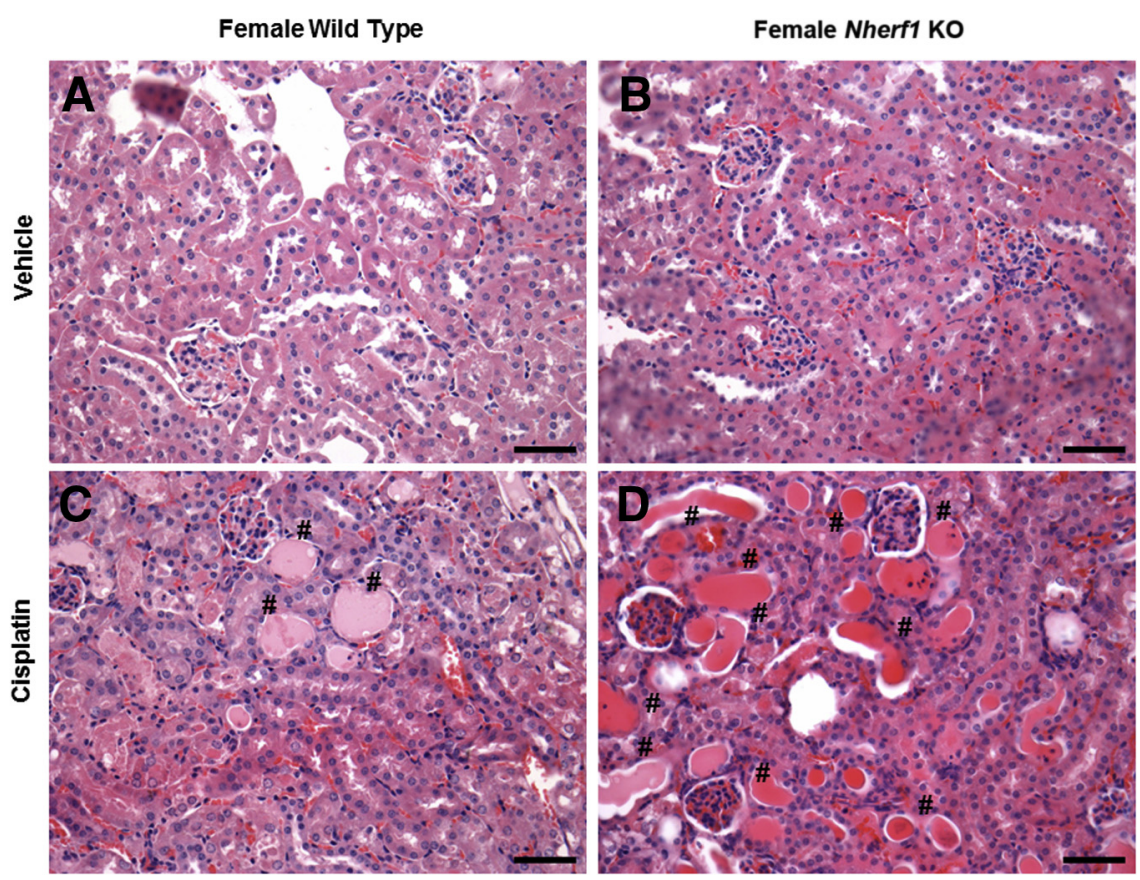

Figure 3 The histologic effect of cisplatin on hematoxylin and eosin (H\&E) in female wild-type (WT) and Nherf1 knockout (KO) mice. Representative photomicrographs of H\&E staining of whole kidney sections embedded in paraffin and cut at 5 $\mu \mathrm{m}$ thick either transversely or longitudinally from cisplatin- and vehicle-treated WT and Nherf1 KO female animals. A-D: A vehicle-treated female WT kidney (A), a vehicle-treated female Nherf1 KO kidney (B), a cisplatin-treated female WT kidney (C), and a cisplatin-treated female Nherf1 KO kidney (D). Pound signs indicate tubular casts. Scale bars: $50 \mu \mathrm{m}$. Original magnification, $\times 40$.

with IBM SPSS Statistics version 24 (IBM, Armonk, NY). $P$ values of $<0.05$ were considered statistically significant.

\section{Results}

Cisplatin treatment was associated with significantly increased BUN level and urine NGAL protein in Nherfl KO mice in comparison to cisplatin-treated WT.

To determine whether cisplatin treatment affected kidney function in Nherfl KO mice to a greater degree than in WT mice, male and female 2-month-old mice were treated with cisplatin to induce AKI and sacrificed after 72 hours. Blood samples were collected and plasma was separated for BUN measurement as described in Materials and Methods. There were no significant differences in baseline BUN between vehicle-treated WT and Nherfl KO mice, regardless of sex (Figure 1A). With cisplatin treatment, both WT mice (male, $93.0 \pm 8.4 \mathrm{mg} / \mathrm{dL}$; female, $101.9 \pm 17.9 \mathrm{mg} / \mathrm{dL}$ ) and Nherf1 KO mice (male, $139 \pm 11.4 \mathrm{mg} / \mathrm{dL}$; female, $163.8 \pm 33.4$ $\mathrm{mg} / \mathrm{dL}$ ) had significant increases in BUN compared to vehicle-treated WT mice (male, $28.5 \pm 3.2 \mathrm{mg} / \mathrm{dL}$; female,

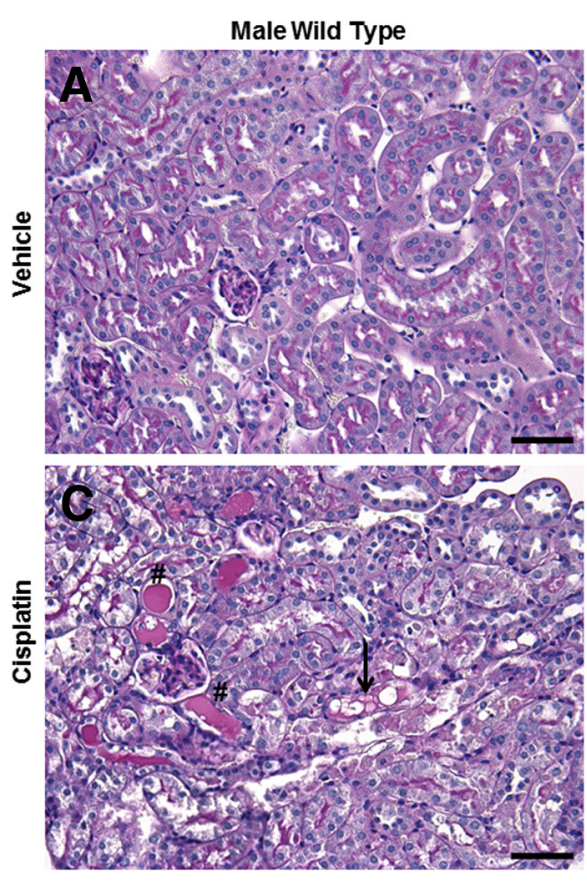

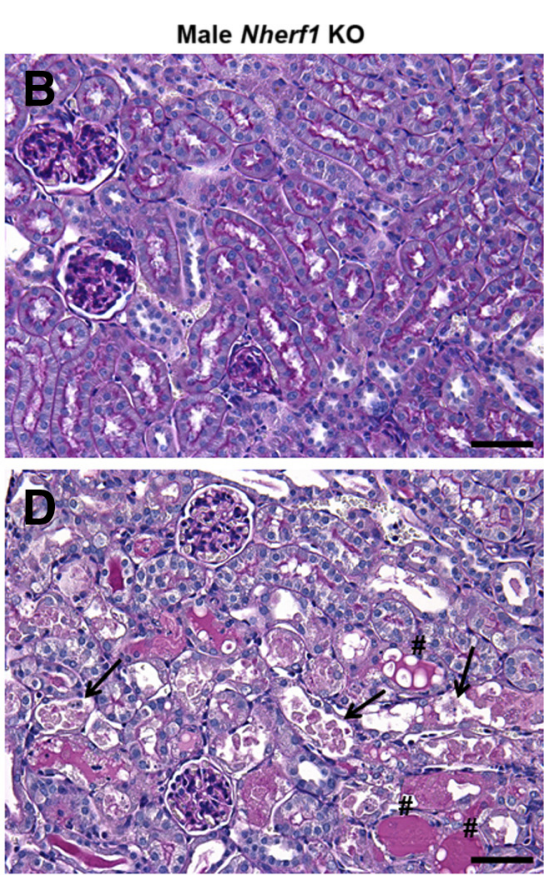

Figure 4 The histologic effect of cisplatin on periodic acid-Schiff (PAS) in male wild-type (WT) and Nherf1 knockout (KO) mice. Representative photomicrographs of PAS staining of whole kidney sections embedded in paraffin and cut at $5 \mu \mathrm{m}$ thick either transversely or longitudinally from cisplatin- and vehicle-treated WT and Nherf1 KO male animals. A vehicle-treated male WT kidney (A), a vehicle-treated male Nherf1 K0 kidney (B), a cisplatin-treated male WT kidney (C), and a cisplatin-treated male Nherf1 KO kidney (D). Arrows indicate acute tubular necrosis; pound signs indicate tubular casts. Scale bars: $50 \mu \mathrm{m}$. Original magnification, $\times 40$. 

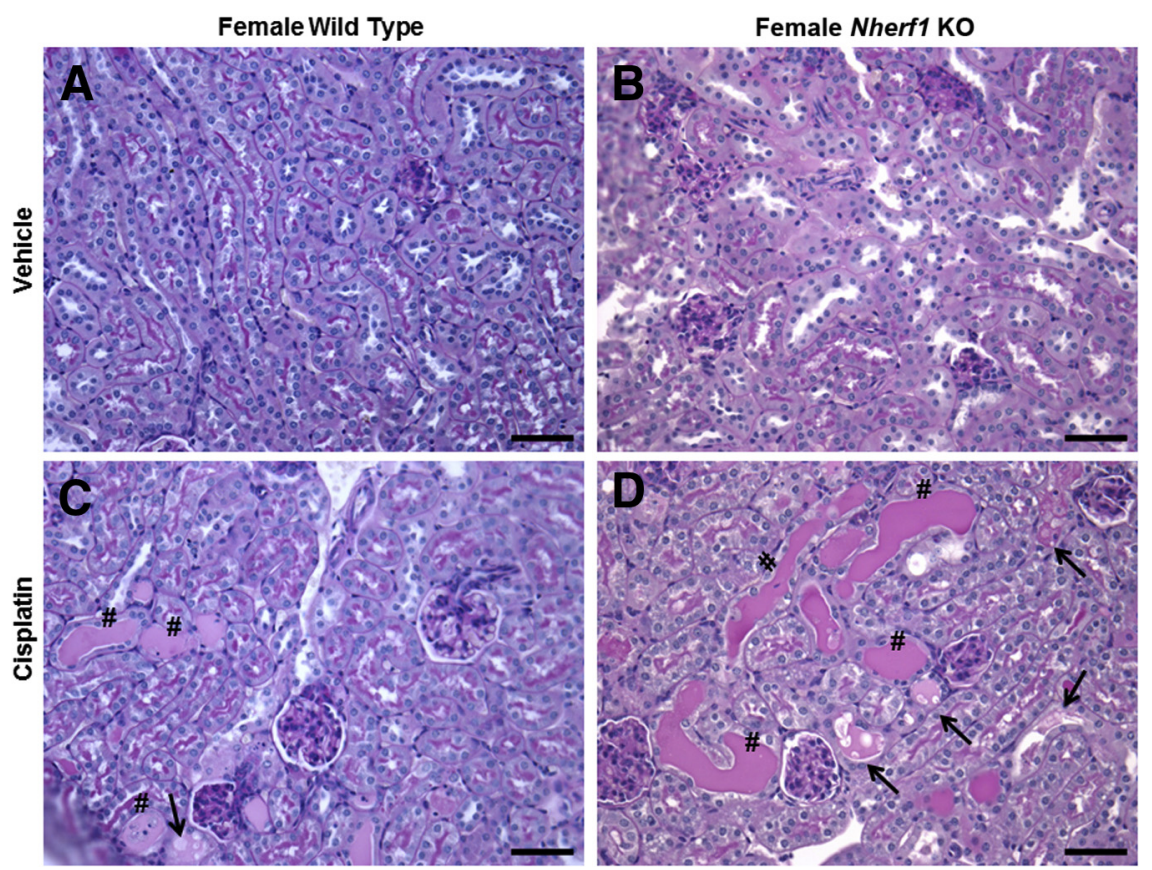

Figure 5 The histologic effect of cisplatin on periodic acid-Schiff (PAS) in female wild-type (WT) and Nherf1 knockout (KO) mice. A-D: Representative photomicrographs of PAS staining of whole kidney sections embedded in paraffin and cut at $5 \mu \mathrm{m}$ thick either transversely or longitudinally from cisplatin- and vehicle-treated WT and Nherf1 K0 female animals. A vehicle-treated female WT kidney (A), a vehicle-treated female Nherf1 K0 kidney (B), a cisplatin-treated female WT kidney $(\mathbf{C})$, and a cisplatin-treated female Nherf1 K0 kidney (D). Arrows indicate acute tubular necrosis; pound signs indicate tubular casts. Scale bars: $50 \mu \mathrm{m}$. Original magnification, $\times 40$.
$25.2 \pm 3.9 \mathrm{mg} / \mathrm{dL})$ and vehicle-treated Nherf1 $\mathrm{KO}$ mice (male, $31.5 \pm 3.7 \mathrm{mg} / \mathrm{dL}$; female, $38.0 \pm 2.2 \mathrm{mg} / \mathrm{dL}$ ) $(P<0.001)$ (Figure 1A). However, a statistically significant increase in BUN level was observed in cisplatin-treated
Nherf1 KO compared to cisplatin-treated WT mice $(P<0.05)$ (Figure 1A). No statistical differences between sexes of the mice or levels of BUN were found under baseline conditions or with cisplatin treatment (Figure 1A).
PAS Normal

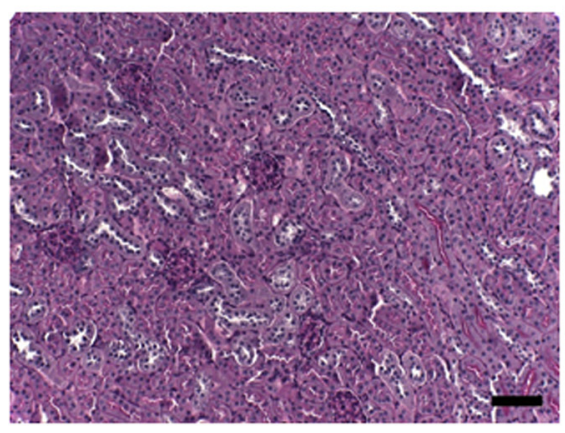

PAS Moderate

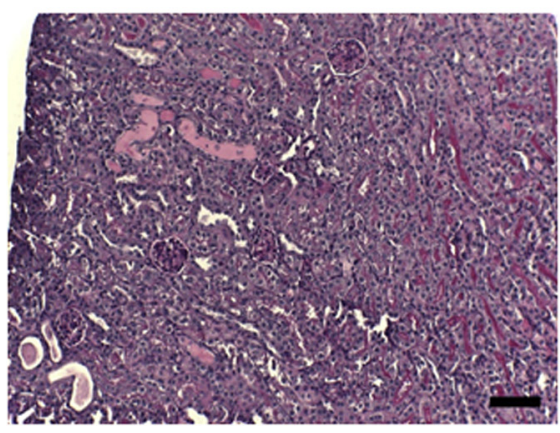

PAS Mild

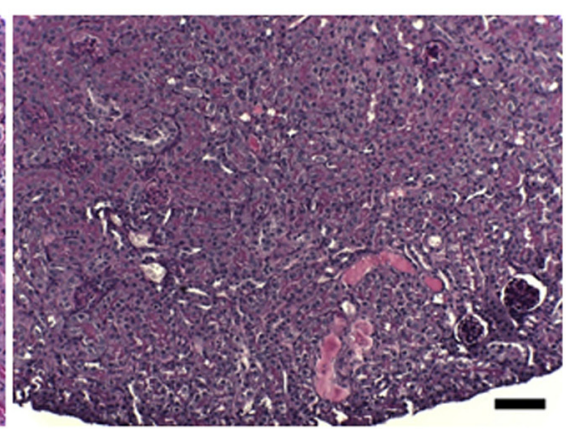

H\&E Mild ATN

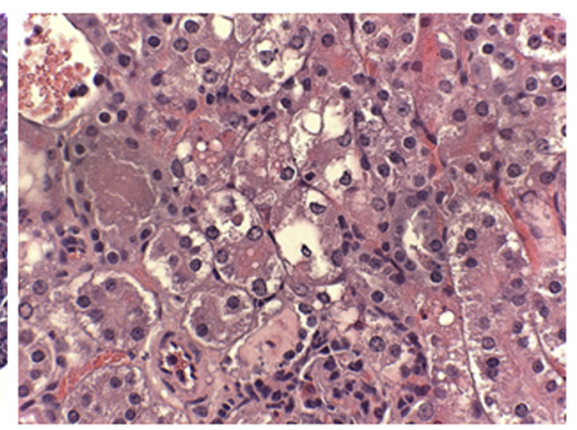

PAS Severe

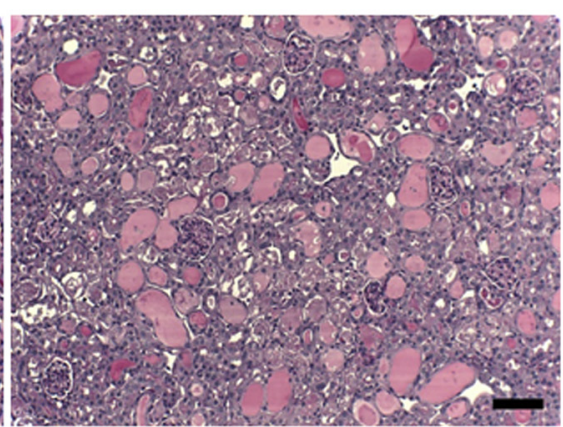

PAS Severe ATN

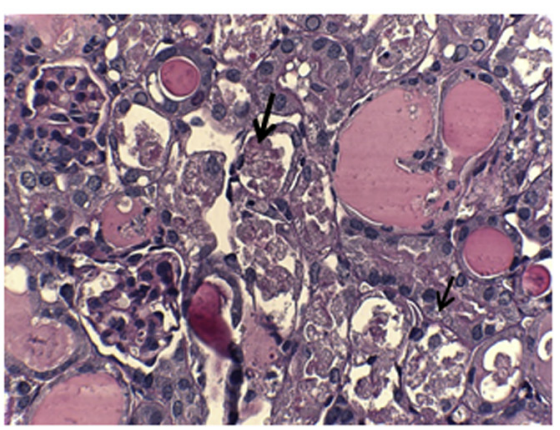

Figure 6 Examples of normal, mild, moderate, and severe injury for semiquantitative scoring. Representative hematoxylin and eosin (H\&E) and periodic acid-Schiff (PAS) staining of whole kidney sections embedded in paraffin and cut at $5 \mu \mathrm{m}$ thick either transversely or longitudinally from cisplatin- and vehicletreated wild-type and Nherf1 knockout male and female animals. Examples of normal, mild, moderate, severe injury, and acute tubular necrosis (ATN; arrows) scoring are shown. Scale bars: $50 \mu \mathrm{m}$. Original magnification: $\times 20$ (left and middle columns); $\times 60$ (right column) 


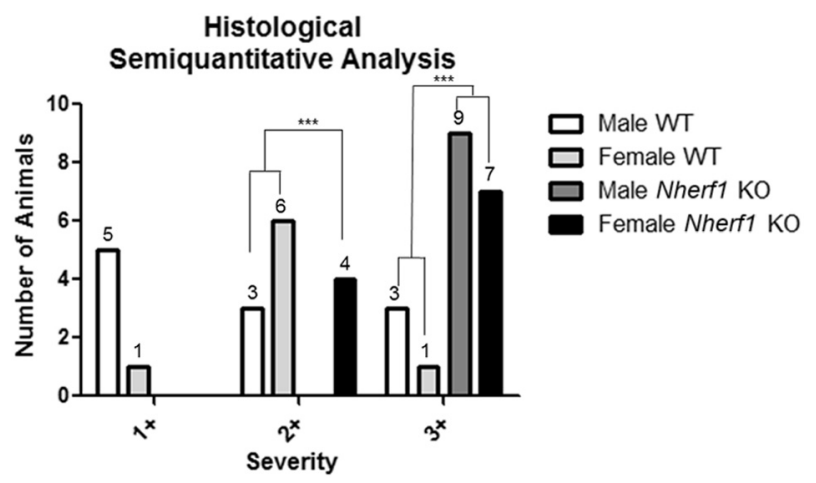

Figure 7 Histologic semiquantitative scoring of cisplatin-treated wildtype (WT) and Nherf1 knockout (KO) mice. Ordinal regression analysis of the semiquantitative scoring. Data are expressed as the numbers of animals with $1+, 2+$, and $3+$ severity scores. $n=8$ (WT female); $n=9$ (Nherf1 K0 male); $n=11$ (WT male and Nherf1 K0 female). ${ }^{* * *} P<0.001$.

Urine samples were collected and NGAL was measured as described in Materials and Methods. With cisplatin treatment, both WT mice (male, $3.4 \pm 1.8 \mu \mathrm{g} / \mathrm{mL}$; female, $2.5 \pm 0.4 \mu \mathrm{g} / \mathrm{mL}$ ) and Nherf1 KO mice (male, $21.5 \pm 13.9$ $\mu \mathrm{g} / \mathrm{mL}$; female, $82.8 \pm 33.1 \mu \mathrm{g} / \mathrm{mL}$ ) had significant increases in NGAL protein compared to vehicle-treated WT mice (male, $0.03 \pm 0.01 \mu \mathrm{g} / \mathrm{mL}$; female, $0.02 \pm 0.006 \mu \mathrm{g} /$ $\mathrm{mL}$ ) and vehicle-treated Nherfl $\mathrm{KO}$ mice (male, $0.01 \pm 0.006 \mu \mathrm{g} / \mathrm{dL}$; female, $0.02 \pm 0.005 \mu \mathrm{g} / \mathrm{mL})$ $(P<0.01)$ (Figure 1B). However, a statistically significant increase in NGAL protein level was observed in cisplatintreated Nherfl KO compared to cisplatin-treated WT mice $(P<0.05)$ (Figure 1B). A significant decrease in NGAL protein was found in vehicle-treated Nherfl $\mathrm{KO}$ mice compared to vehicle-treated WT mice $(P<0.05)$ (Figure 1B). No statistical differences between sexes of the mice and NGAL protein were found under baseline conditions or with cisplatin treatment (Figure 1B).

\section{Effects of Cisplatin Treatment on Kim1 mRNA Expression in WT and Nherf1 KO Mice}

Kiml mRNA expression was not significantly different between WT and Nherfl KO vehicle-treated mice (Figure 1C). However, Kiml mRNA expression was significantly increased in both cisplatin-treated WT mice (male, $2363.5 \pm 1182.1$-fold of control; female, $724.6 \pm 386.3$ fold of control) and Nherfl KO mice (male, $4514.2 \pm 3157.4$-fold of control; female, $1175.2 \pm 295.7-$ fold of control $)(P<0.05)$ in comparison to vehicletreated WT mice (male, $0.9 \pm 0.4$-fold of control; female, $0.5 \pm 0.2$-fold of control) and Nherfl KO mice (male, $3.3 \pm 0.9$-fold of control; female, $1.6 \pm 0.7$-fold of control) (Figure 1C). There was no significant difference in the kidney expression of Kiml mRNA with cisplatin treatment between WT and Nherfl KO mice; no statistical difference between sexes or Kiml mRNA expression was found.

\section{WT Male Vehicle}

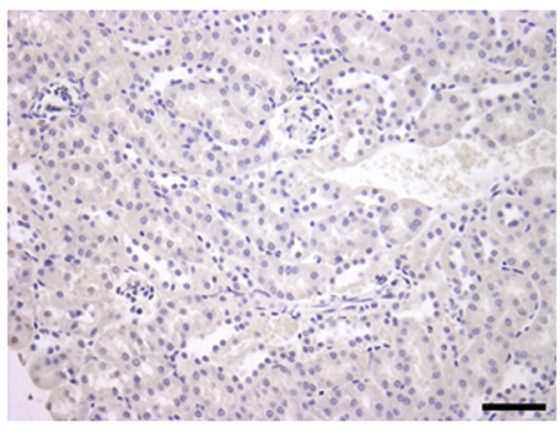

Nherf1 Ko Male Vehicle

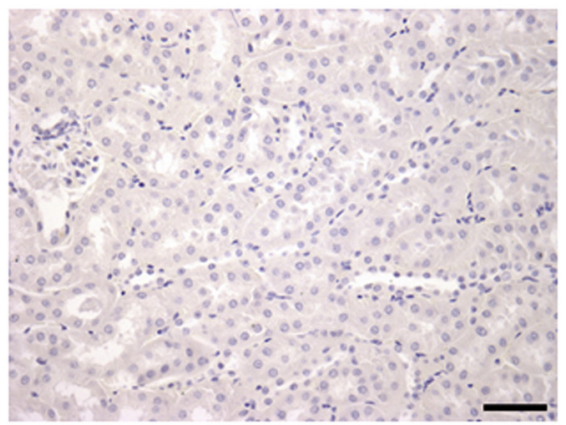

WT Male Cisplatin

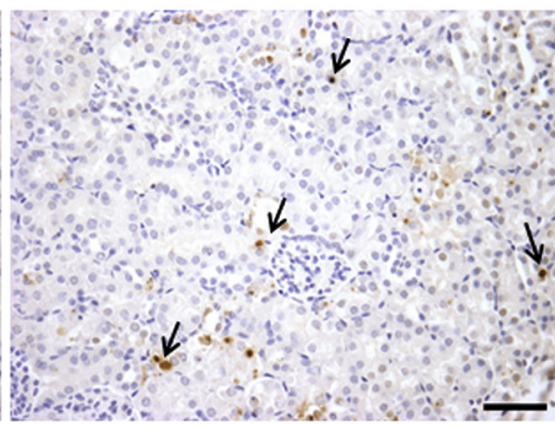

Nherf1 KO Male Cisplatin

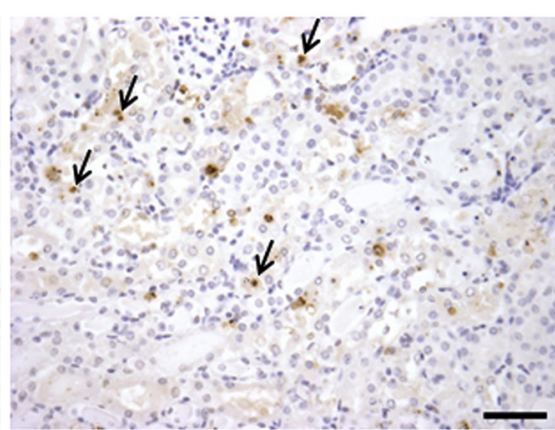

WT Female Cisplatin

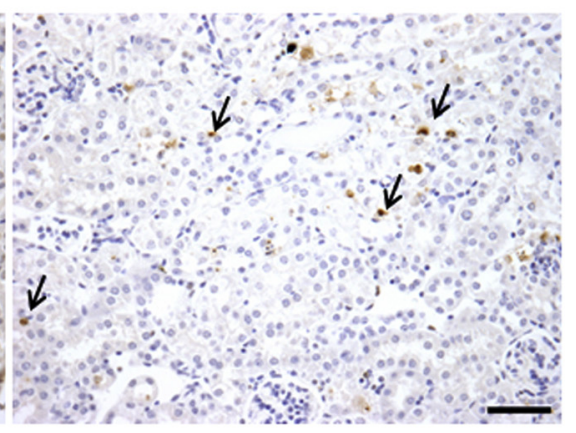

Nherf1 KO Female Cisplatin

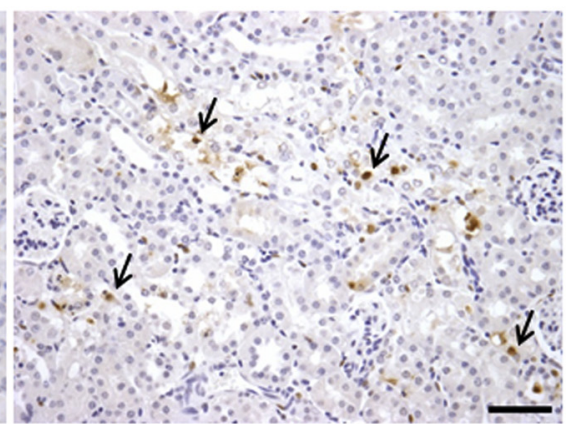

Figure 8 Terminal deoxynucleotidyl transferase dUTP nick end labeling (TUNEL) assay photomicrographs of vehicle- and cisplatin-treated wild-type (WT) and Nherf1 (KO) mice. Representative photomicrographs of vehicle- and cisplatin-treated WT and Nherf1 KO male and female mice and TUNEL-positive nuclei (arrows). TUNEL-positive nuclei were seen in the kidney of animals that received cisplatin. Scale bars $=50 \mu \mathrm{m}$. 
Severity of Renal Injury in Cisplatin-Treated Nherf1 K0 Mice

$\mathrm{H} \& \mathrm{E}$ and PAS staining of the kidneys in cisplatin-treated Nherfl KO mice showed that the injury was predominantly cortical (Figures 2, 3, 4, and 5). H\&E (Figures 2 and 3) and PAS (Figures 4 and 5) staining revealed that kidneys from vehicle-treated WT and Nherfl KO mice were histologically similar, with no structural differences (Figures 2, 3, 4, and 5). As has been observed previously in $\mathrm{H} \& \mathrm{E}$ and PAS staining, ${ }^{20,21}$ cisplatin treatment in WT mouse kidneys resulted in visible histologic damage, primarily in the proximal tubules (Figures 2, 3, 4, and 5). This damage was manifested by severe cell damage, casts, atrophy, brush border membrane sloughing, and acute tubular necrosis. With cisplatin treatment, Nherfl KO mice had a visibly greater degree of histologic damage seen with both H\&E (Figures 2 and 3) and PAS (Figures 4 and 5) staining.

To quantitate the differences in the degree of histologic damage between cisplatin-treated WT and Nherfl KO mice, kidney sections were sent to a pathologist (S.C.) for semiquantitative scoring in a blinded study, as described in Histology and Semiquantitative Scoring (Figure 6). The histology of all vehicle-treated mice, regardless of genotype (WT or Nherf1 KO), was assessed as normal (score, 0), without injury. The severities of injury in the cisplatintreated WT kidneys were graded as mild $(1+)$ in 6 mice, moderate $(2+)$ in 9 , and severe $(3+)$ in 4 (Figure 7). In contrast, the injury in majority $(n=16)$ of kidneys from the cisplatin-treated Nherfl $\mathrm{KO}$ animals fell under the category of severe (3+), and none of the cisplatin-treated Nherfl KO kidneys were graded as having mild injury (Figure 7). The vehicle-treated kidneys in the WT $(n=20)$ and Nherfl $(n=22)$ groups are not shown in Figure 7 . The mean injury scores were 1.89 in the WT group and 2.8 in the Nherfl KO group $(P<0.001)$ (Figure 7 ).

\section{Degrees of Apoptosis in Cisplatin-Treated WT and Nherf1 K0 Mice}

To compare the degree of apoptosis in WT versus Nherfl KO mouse kidneys, two different assays for apoptosis were performed, TUNEL and caspase 3 cleavage. Kidney sections were subjected to TUNEL analysis (Figures 8 and 9). TUNEL assay analysis showed significantly increased degrees of apoptosis (measured as the number of positive nuclei per number of visual fields) in both cisplatin-treated Nherf1 KO mice (male, $12.9 \pm 2.5$; female, $11.3 \pm 3.2$ ) and WT mice (male, $10.6 \pm 1.4$; female, $8.3 \pm 1.4$ ) in comparison to vehicle-treated Nherfl $\mathrm{KO}$ mice (male, $0.2 \pm$ 0.06 ; female, $0.2 \pm 0.05$ ) and WT mice (male, $0.1 \pm 0.05$; female, $0.03 \pm 0.02)(P<0.001)$ (Figure 9). There were no significant differences in the levels of apoptosis between the cisplatin-treated WT and Nherfl KO mice or between the vehicle-treated WT and Nherfl KO mice (Figure 9), despite

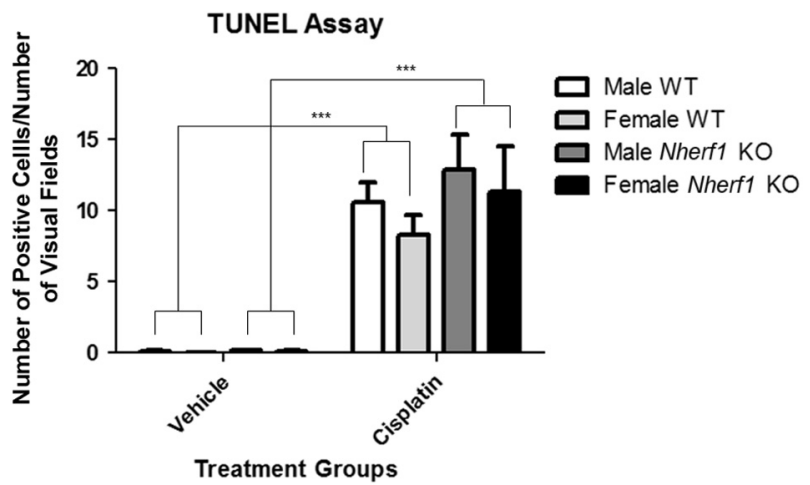

Figure 9 Terminal deoxynucleotidyl transferase dUTP nick end labeling (TUNEL) assay of vehicle- and cisplatin-treated wild-type (WT) and Nherf1 knockout (KO) mice. Quantitation of TUNEL-positive nuclei was performed in a blinded fashion (A.B.-S.) and only positively stained nuclei exhibiting characteristics of apoptotic nuclei were included. Twenty to 30 randomly chosen visual fields were observed under a $\times 40$ objective as described in the Materials and Methods. Data are expressed as mean \pm SEM ratios between the number of TUNEL-positive nuclei and the total number of visual fields. $n=7$ (Nherf1 K0 male vehicle); $n=10$ (WT male vehicle, WT female vehicle, Nherf1 KO female vehicle, WT male cisplatin, WT female cisplatin, Nherf1 K0 male cisplatin, and Nherf1 K0 female cisplatin). ${ }^{* * *} P<0.001$ (three-way analysis of variance).

a greater degree of tubular necrosis observed in the kidneys of the cisplatin-treated Nherfl KO mice (Figure 4).

To confirm the TUNEL assay findings, cleaved caspase 3, the activated terminal component of the caspase cascade, was analyzed via Western blot analysis. A significant increase in cleaved caspase 3 expression was demonstrated in cisplatintreated WT and Nherfl KO mouse kidneys compared to their respective vehicle-treated controls $(P<0.01)$ (Figure 10), but the difference in cleaved caspase 3 expression between cisplatin-treated WT and Nherfl KO mouse kidneys was not significant. Interestingly, a significant sex difference was documented, with an increase in cleaved caspase 3 expression in female vehicle-treated compared to male vehicle-treated mouse WT and KO kidneys $(P<0.05)$ (Figure 10$)$.

\section{Discussion}

The goal of this study was to determine whether NHERF1 loss results in increased susceptibility to cisplatin-induced AKI. This is the first study to investigate the role of NHERF1 in cisplatin-induced AKI, and the first to show that Nherfl KO mice have increased susceptibility to cisplatin-induced AKI.

The baseline BUN of vehicle-treated Nherfl KO mice was comparable to that in vehicle-treated WT mice, indicating that renal function is similar under baseline conditions. Nherfl KO mice exhibit significant differences in the expression of brush border membrane proteins of the small intestine, ${ }^{22}$ suggesting that Nherf1 KO mice might experience chronic volume depletion due to poor gastrointestinal solute absorption, which could be a mechanism for increased susceptibility to toxininduced AKI. However, the similar baseline BUN levels 


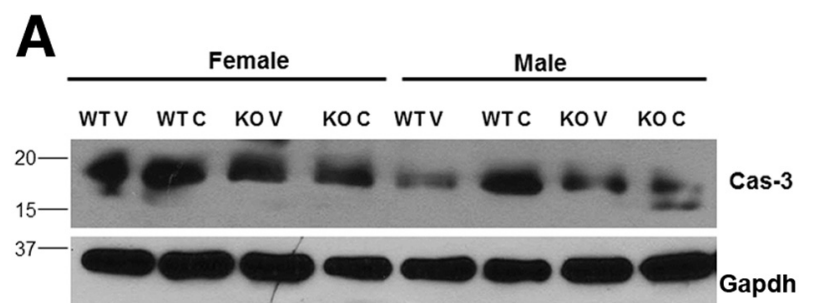

B

Cleaved Caspase 3 Protein Expression

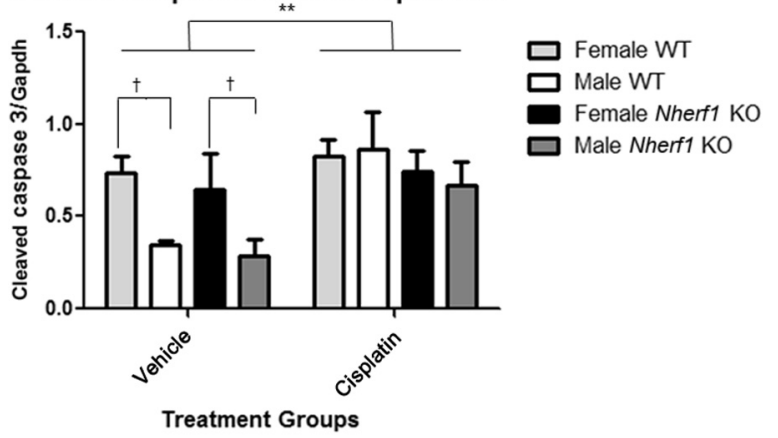

Figure 10 Effect of cisplatin on cleavage of caspase 3 in wild-type (WT) and Nherf1 knockout (K0) mice. A: Representative blots of cleaved caspase (Cas)-3 and glyceraldehyde-3-phosphate dehydrogenase (Gapdh). Kidney homogenates were separated by $10 \%$ SDS-PAGE and transferred to nitrocellulose membranes. Quantitation was performed as described in Materials and Methods of cleaved caspase 3 (both 17 and 19 kDa bands). B: A representative blot from four independent experiments. Data are expressed as means \pm SEM (B). $n=4$ mice per treatment group. ${ }^{*} P<0.01$ cisplatin treatment compared to vehicle alone; ${ }^{\dagger} P<0.05$ females compared to males alone (three-way analysis of variance). C., cleaved; KOC, knockout, cisplatin; KOV, knockout, vehicle; WTC, wild-type, cisplatin; WTV, wild-type, vehicle.

coupled with those from prior studies showing similar blood pressure and urine sodium excretion ${ }^{19}$ do not suggest chronic volume depletion in the Nherfl $\mathrm{KO}$ animals, thus decreasing the likelihood of this mechanism in the increased susceptibility of Nherfl KO mice to cisplatin-induced AKI. Cisplatin increased BUN and NGAL in both WT and Nherfl KO mice, with the cisplatin-treated Nherfl KO mice having significantly higher BUN and NGAL than cisplatin-treated WT mice. These results are consistent with a significantly greater decrease in renal function in Nherfl KO animals when challenged with cisplatin.

The findings on histologic comparison of the kidneys of WT and Nherf1 KO animals support the biochemical data. The kidneys of vehicle-treated WT and Nherf1 KO mice were morphologically and structurally similar. Cisplatin treatment in Nherfl KO mice was associated with a greater severity of injury, and an overall severity score that was significantly higher than the score in WT mice. Furthermore, a significantly higher number of cisplatin-treated Nherfl KO mice were found to have the most severe injury (3+) compared to cisplatin-treated WT mice.

Kim-1, a sensitive marker of kidney tubular injury, was significantly increased with cisplatin treatment in WT and Nherfl KO mice. Kim-1 was not increased in baseline measurements in vehicle-treated WT and Nherfl KO mice, indicating that under baseline conditions, Nherfl KO mice do not have detectable levels of underlying injury. No significant difference in Kim-1 expression levels was found in cisplatin-treated WT and Nherfl KO mouse kidneys. This finding is ostensibly inconsistent with significant differences in histologic damage and BUN levels between WT and Nherfl KO mice treated with cisplatin. However, the histologic kidney sections of cisplatin-treated Nherfl KO mice showed a far greater degree of brush border membrane sloughing and tubular necrosis, which would decrease Kiml mRNA and protein expression. ${ }^{23}$ A previous study evaluating the effect of necrosis on the expression of Kim-1 in the setting of proximal tubule injury in rats demonstrated that Kim-1 expression was present at higher levels in tubules that showed modest levels of necrosis, whereas Kim-1 expression was present at lower levels in tubules with severe levels of necrosis. ${ }^{24}$ The investigators hypothesized that KIM-1 expression may be affected by phagocytic and repair mechanisms in response to injury and therefore is mainly found in nonlethally injured cells. ${ }^{24}$

Cisplatin induces renal proximal tubule cell death through both necrosis and apoptosis. ${ }^{20,25,26}$ TUNEL analysis and cleavage of caspase 3 demonstrated that at 72 hours after cisplatin treatment, apoptosis was increased similarly in both WT and Nherfl KO mouse kidneys. Under baseline vehicletreatment conditions, there was no detectable difference in apoptosis between WT and Nherf1 KO mouse kidneys as measured by TUNEL assay. Overall, these data suggest that the greater degree of injury seen with cisplatin treatment in the Nherfl $\mathrm{KO}$ mice was a result of increased cell death via tubular necrosis when compared with the WT animals. Interestingly, there was a significant difference in baseline caspase 3 cleavage between male and female mice, with the female mice showing significantly higher levels of caspase 3 cleavage product, independent of genotype. The significance of this finding is unknown at this time, as no other sex differences related to kidney injury were found in this study.

This study demonstrates a novel role for NHERF1 in protection against cisplatin-induced AKI. NHERF1 has been identified as a trafficking protein and a scaffolding protein that is involved in the formation of multiprotein complexes. Additionally, NHERF1 has importance in metabolism. ${ }^{27}$ Therefore, several potential mechanisms may explain the susceptibility to cisplatin, including mitochondrial dysfunction, changes in metabolic pathways, alterations in intracellular signaling, ${ }^{28-30}$ decreased ATP production due to hypophosphatemia, ${ }^{31}$ changes in renal handling of cisplatin, ${ }^{32-35}$ and/or reduction in regeneration capabilities of proximal tubules. These findings have potential clinical significance. Aging rats (22 months) show a decrease in Nherf1 expression. ${ }^{17}$ Clinically, the elderly population experience greater cancer prevalence and are more likely to develop AKI in response to insults such as that associated with cisplatin use. $^{36,37}$ Thus, in the elderly population, NHERF1 loss may occur and contribute to the risk for AKI. Potentially, 
NHERF1 expression could be used as a biomarker for susceptibility to AKI or as a target for innovative therapies to protect against cisplatin-induced AKI.

\section{Acknowledgments}

We thank Susan Isaacs for expert technical support and the Division of Nephrology for financial support.

A.B-S. was the primary investigator on this project and performed all experiments and was the primary author of the manuscript; M.B. assisted technically with staining and imaging and edited the manuscript; C.C. assisted technically with experiments and edited the manuscript; T.D. assisted with animal treatments; K.B.G. assisted with tissue collection; S.J.K provided editing assistance with the manuscript; B.C. provided technical and intellectual assistance with experiments; L.S. provided technical and intellectual assistance with KIM-1 experiments; M.A.D. performed ELISA assay for NGAL; M.R. performed experiments for cleavage of caspase 3; M.B. provided expert statistical analysis for all experiments; S.C. provided all semiquantitative scoring of kidney sections from the experiments; E.D.L. is the mentor of the primary investigator, provided intellectual/conceptual input into experimental design and results analysis, and edited the manuscript; E.D.L. is the guarantor of this work and had full access to all of the data in this study and takes full responsibility for the integrity of the data and the accuracy of the data analysis.

\section{References}

1. Ozkok A, Edelstein CL: Pathophysiology of cisplatin-induced acute kidney injury. Biomed Res Int 2014, 2014:967826

2. Miller RP, Tadagavadi RK, Ramesh G, Reeves WB: Mechanisms of cisplatin nephrotoxicity. Toxins 2010, 2:2490-2518

3. de Mendonca A, Vincent JL, Suter PM, Moreno R, Dearden NM, Antonelli M, Takala J, Sprung C, Cantraine F: Acute renal failure in the ICU: risk factors and outcome evaluated by the SOFA score. Intensive Care Med 2000, 26:915-921

4. Ferguson MA, Vaidya VS, Bonventre JV: Biomarkers of nephrotoxic acute kidney injury. Toxicology 2008, 245:182-193

5. Chertow GM, Levy EM, Hammermeister KE, Grover F, Daley J: Independent association between acute renal failure and mortality following cardiac surgery. Am J Med 1998, 104:343-348

6. Ramesh G, Reeves WB: Inflammatory cytokines in acute renal failure. Kidney Int Suppl 2004:S56-S61

7. Yao X, Panichpisal K, Kurtzman N, Nugent K: Cisplatin nephrotoxicity: a review. Am J Med Sci 2007, 334:115-124

8. Ciarimboli G: Membrane transporters as mediators of cisplatin effects and side effects. Scientifica (Cairo) 2012, 2012:473829

9. Khundmiri SJ, Weinman EJ, Steplock D, Cole J, Ahmad A, Baumann PD, Barati M, Rane MJ, Lederer E: Parathyroid hormone regulation of $\mathrm{NA}+, \mathrm{K}+$-ATPase requires the PDZ 1 domain of sodium hydrogen exchanger regulatory factor-1 in opossum kidney cells. J Am Soc Nephrol 2005, 16:2598-2607

10. Cheng H, Li J, Fazlieva R, Dai Z, Bu Z, Roder H: Autoinhibitory interactions between the PDZ2 and C-terminal domains in the scaffolding protein NHERF1. Structure 2009, 17:660-669
11. Cunningham R, Biswas R, Steplock D, Shenolikar S, Weinman E: Role of NHERF and scaffolding proteins in proximal tubule transport. Urol Res 2010, 38:257-262

12. Weinman EJ, Steplock D, Wang Y, Shenolikar S: Characterization of a protein cofactor that mediates protein kinase A regulation of the renal brush border membrane $\mathrm{Na}(+)-\mathrm{H}+$ exchanger. J Clin Invest 1995, 95 : 2143-2149

13. Dai JL, Wang L, Sahin AA, Broemeling LD, Schutte M, Pan Y: NHERF $(\mathrm{Na}+/ \mathrm{H}+$ exchanger regulatory factor $)$ gene mutations in human breast cancer. Oncogene 2004, 23:8681-8687

14. Georgescu MM, Morales FC, Molina JR, Hayashi Y: Roles of NHERF1/EBP50 in cancer. Curr Mol Med 2008, 8:459-468

15. Al Ghouleh I, Meijles DN, Mutchler S, Zhang Q, Sahoo S, Gorelova A, Henrich Amaral J, Rodriguez AI, Mamonova T, Song GJ, Bisello A, Friedman PA, Cifuentes-Pagano ME, Pagano PJ: Binding of EBP50 to Nox organizing subunit p47phox is pivotal to cellular reactive species generation and altered vascular phenotype. Proc Natl Acad Sci U S A 2016, 113:E5308-E5317

16. Li M, Mennone A, Soroka CJ, Hagey LR, Ouyang X, Weinman EJ, Boyer JL: $\mathrm{Na}(+) / \mathrm{H}(+)$ exchanger regulatory factor 1 knockout mice have an attenuated hepatic inflammatory response and are protected from cholestatic liver injury. Hepatology 2015, 62:1227-1236

17. Barati MT, Ketchem CJ, Merchant ML, Kusiak WB, Jose PA, Weinman EJ, LeBlanc AJ, Lederer ED, Khundmiri SJ: Loss of NHERF-1 expression prevents dopamine-mediated Na-K-ATPase regulation in renal proximal tubule cells from rat models of hypertension: aged F344 rats and spontaneously hypertensive rats. Am J Physiol Cell Physiol 2017, 313:C197-C206

18. Khundmiri SJ, Ahmad A, Bennett RE, Weinman EJ, Steplock D, Cole J, Baumann PD, Lewis J, Singh S, Clark BJ, Lederer ED: Novel regulatory function for NHERF-1 in Npt2a transcription. Am J Physiol Renal Physiol 2008, 294:F840-F849

19. Shenolikar S, Voltz JW, Minkoff CM, Wade JB, Weinman EJ: Targeted disruption of the mouse NHERF-1 gene promotes internalization of proximal tubule sodium-phosphate cotransporter type IIa and renal phosphate wasting. Proc Natl Acad Sci U S A 2002, 99:11470-11475

20. Dobyan DC, Levi J, Jacobs C, Kosek J, Weiner MW: Mechanism of cis-platinum nephrotoxicity: II. Morphologic observations. J Pharmacol Exp Ther 1980, 213:551-556

21. Dobyan DC: Long-term consequences of cis-platinum-induced renal injury: a structural and functional study. Anat Rec 1985, 212: 239-245

22. Donowitz M, Singh S, Singh $\mathrm{P}$, Salahuddin FF, Chen $\mathrm{Y}$, Chakraborty M, Murtazina R, Gucek M, Cole RN, Zachos NC, Kovbasnjuk O, Broere N, Smalley-Freed WG, Reynolds AB, Hubbard AL, Seidler U, Weinman E, de Jonge HR, Hogema BM, Li X: Alterations in the proteome of the NHERF1 knockout mouse jejunal brush border membrane vesicles. Physiol Genomics 2010, 42A: 200-210

23. Alge JL, Arthur JM: Biomarkers of AKI: a review of mechanistic relevance and potential therapeutic implications. Clin J Am Soc Nephrol 2015, 10:147-155

24. Prozialeck WC, Edwards JR, Lamar PC, Liu J, Vaidya VS, Bonventre JV: Expression of kidney injury molecule-1 (Kim-1) in relation to necrosis and apoptosis during the early stages of Cdinduced proximal tubule injury. Toxicol Appl Pharmacol 2009, 238:306-314

25. Cummings BS, Schnellmann RG: Cisplatin-induced renal cell apoptosis: caspase 3-dependent and -independent pathways. J Pharmacol Exp Ther 2002, 302:8-17

26. Lieberthal W, Triaca V, Levine J: Mechanisms of death induced by cisplatin in proximal tubular epithelial cells: apoptosis vs. necrosis. Am J Physiol 1996, 270:F700-F708

27. Vaquero J, Nguyen Ho-Bouldoires TH, Claperon A, Fouassier L: Role of the PDZ-scaffold protein NHERF1/EBP50 in cancer biology: from signaling regulation to clinical relevance. Oncogene 2017, 36: 3067-3079 
28. Taylor CW, Tovey SC: From parathyroid hormone to cytosolic Ca2+ signals. Biochem Soc Trans 2012, 40:147-152

29. Ardura JA, Friedman PA: Regulation of G protein-coupled receptor function by $\mathrm{Na}+/ \mathrm{H}+$ exchange regulatory factors. Pharmacol Rev 2011, 63:882-900

30. Wang B, Ardura JA, Romero G, Yang Y, Hall RA, Friedman PA: $\mathrm{Na} / \mathrm{H}$ exchanger regulatory factors control parathyroid hormone receptor signaling by facilitating differential activation of G(alpha) protein subunits. J Biol Chem 2010, 285:26976-26986

31. Pesta DH, Tsirigotis DN, Befroy DE, Caballero D, Jurczak MJ, Rahimi Y, Cline GW, Dufour S, Birkenfeld AL, Rothman DL, Carpenter TO, Insogna K, Petersen KF, Bergwitz C, Shulman GI: Hypophosphatemia promotes lower rates of muscle ATP synthesis. FASEB J 2016, 30:3378-3387

32. Hanigan MH, Gallagher BC, Taylor PT Jr, Large MK: Inhibition of gamma-glutamyl transpeptidase activity by acivicin in vivo protects the kidney from cisplatin-induced toxicity. Cancer Res 1994, 54: 5925-5929

33. Townsend DM, Hanigan MH: Inhibition of gamma-glutamyl transpeptidase or cysteine S-conjugate beta-lyase activity blocks the nephrotoxicity of cisplatin in mice. J Pharmacol Exp Ther 2002, 300:142-148

34. Townsend DM, Deng M, Zhang L, Lapus MG, Hanigan MH: Metabolism of cisplatin to a nephrotoxin in proximal tubule cells. J Am Soc Nephrol 2003, 14:1-10

35. Hanigan MH, Devarajan P: Cisplatin nephrotoxicity: molecular mechanisms. Cancer Ther 2003, 1:47-61

36. Berger NA, Savvides P, Koroukian SM, Kahana EF, Deimling GT, Rose JH, Bowman KF, Miller RH: Cancer in the elderly. Trans Am Clin Climatol Assoc 2006, 117:147-155. discussion 155-6

37. Pascual J, Orofino L, Liano F, Marcen R, Naya MT, Orte L, Ortuno J: Incidence and prognosis of acute renal failure in older patients. J Am Geriatr Soc 1990, 38:25-30 